НЕРУБАЦЬКИЙ В. П., к.т.н., доцент (УкрДУЗТ),

ПЛАХТІЙ О. А., к.т.н., доцент (УкрДУЗТ),

МАШУРА А. В., аспірант (НТУ «ХПІ»),

ГОРДІЄНКО Д. А., аспірант (УкрДУЗТ)

\title{
Аналіз технічних характеристик акумуляторних батарей і систем заряджання електромобілів
}

У статті представлено класифікачію електромобілів $і$ проведено огляд технічних характеристик акумуляторних батарей $i$ їх систем заряджання. На сьогодні найбільш перспективними $\epsilon$ літій-іонні акумулятори. Вони мають такі переваги: високий коефіцієнт корисної дї в процесі заряджання-розряджання, висока щуільність електричної енергї (кВт·год/кг). При изьому відносним недоліком літій-іонних акумуляторів $\epsilon$ невелика кількість ичклів заряджання-розряджання (близько 500 ичилів), щчо відповідає приблизно 250 тис. км для електромобіля Tesla Model S, після чого акумуляторну батарею необхідно замінити.

Представлені базові енергетичні параметри та зарядно-розрядні характеристики літій-іонних акумуляторів, які використовуються в електромобілях Tesla.

Виділено та класифіковано чотири типи зарядних станцій, з яких перший тип описує процес заряджання електромобіля безпосередньо від однофазної мережі живлення. Другий тип відрізняється від першого наявністю електричного захисту. Третій тип - заряджання електромобіля трифазною напругою змінного струму. Четвертий тип - заряджання постійним струмом і великою потужністю, щьо дозволяє швидше проводити прочес заряджання.

Ключові слова: акумуляторна батарея, двигун, джерело живлення, електромобіль, зарядно-розрядні характеристики, літій-іонний акумулятор.

\section{Вступ}

Ефективність енерговикористання у промисловості традиційно оцінюється та контролюється шляхом нормування iï питомих витрат, що у свою чергу грунтується на побудові та аналізі енергетичних балансів виробничо-господарських об'єктів [1]. Основною метою є досягнення високої енергетичної ефективності господарської діяльності при плануванні, організації, координуванні, обліку та контролі для оптимального використання всіх видів ресурсів і надання відповідних послуг для забезпечення функціонування об'єкта [2].

В останні декілька десятиліть спостерігається стійкий перехід від транспорту 3 двигунами внутрішнього згоряння до електродвигунів, включаючи поїзди, кораблі та електромобілі. Розширення використання електромобілів (PEV) $\epsilon$ дуже перспективним 3 огляду на можливе зменшення забруднення атмосферного повітря транспортними засобами, насамперед у великих містах [3].

Протягом останніх кількох років технології гібридного електричного транспортного засобу (HEV) та електричного транспортного засобу (EV) забезпечили ефективне рішення для економії палива 3 більш високою продуктивністю і більш низькими викидами порівняно зі звичайними транспортними засобами. Електрифікація автомобільного транспорту в наш час $\epsilon$ одним 3 основних трендів розвитку світової автомобільної галузі. У 2015 р. частка електромобілів у світовому автопарку складала тільки $0,1 \%$, але, за прогнозами, до 2030 р. становитиме близько $10 \%$, а до 2050 р. - близько $40 \%$ [4].

Ще однією перевагою використання електромобілів $\epsilon$ значне зменшення витрат на енергоресурси, а також можливе зменшення витрат на ремонт i технічне обслуговування порівняно зі звичайними автомобілями. Практично у всьому світі електроенергія на сьогодні $\epsilon$ найдешевшим енергоресурсом, що застосовується для транспортних засобів. Так, наприклад, електромобілі Tesla на 100 км у середньому споживають 17 кВт·год, у той час як «бензинові» автомобілі в середньому споживають 7 л палива на 100 км. В Україні електроенергія коштує 1,68 грн за 1 кВт·год, а паливо - 1,14\$.

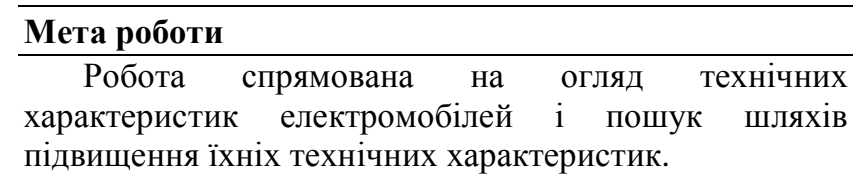

() В. П. Нерубацький, О. А. Плахтій, А. В. Машура, Д. А. Гордіснко, 2019 


\section{Викладення основного матеріалу}

До засобів електротранспорту відносять рейкові та контактно-дротові транспортні засоби (електропоїзди, трамваї, тролейбуси), а також електромобілі EVs (electric vehicles) - автономні колісні транспортні засоби, які повністю або частково працюють на електроприводі [5].

При вирішенні завдань проектування повинні забезпечуватися не тільки різноманітні функціональні можливості, але i модульність конструкції, що $є$ найбільш прийнятним рішенням [6].

Тип електромобілів, які мають можливість заряджатися від зовнішніх джерел живлення, називають PEV (plug-in electric vehicle). Вони поділяються на такі типи:

- електромобілі, оснащені виключно електричними двигунами (одним чи декількома), що живляться лише від електричних акумуляторів і потребують заряджання від зовнішнього зарядного обладнання (battery electric vehicles) - BEVs;

- електромобілі 3 гібридними енергетичними установками, які оснащені як електричними силовими установками (електродвигунами), так i силовими установками на іншому виді палива (наприклад бензиновими або дизельними двигунами) 3 різними формами взаємодії силових установок i мають можливість заряджатися від зовнішніх джерел живлення (plug-in hybrid electric vehicles) - PHEVs [7].

Крім електромобілів PEV, існують, зокрема, електромобілі 3 гібридними енергетичними установками, які не мають можливості заряджатися від зовнішніх джерел живлення i можуть заряджатися лише від бортового зарядного обладнання (hybrid electric vehicles) - HEVs, a також електромобілі 3 гібридними енергетичними установками, що працюють на паливних елементах і теж не мають можливості заряджатися від зовнішніх джерел живлення (fuel cell hybrid electric vehicles) - FCHEVs [8].

Одним 3 ключових елементів, що визначає перспективи розвитку електромобілів, є акумуляторна батарея [9]. Саме від акумуляторної батареї найбільше залежить, 3 одного боку, потенційна дальність пересування електромобілів на одному заряджанні, 3 іншого боку, різниця в ціні 3 традиційними автомобілями 3 двигунами внутрішнього згорання (ДВ3). У табл. 1 наведено порівняння характеристик акумуляторних батарей різних типів.

Таблиця 1

Порівняння характеристик акумуляторних батарей різних типів

\begin{tabular}{|c|c|c|c|c|}
\hline $\begin{array}{l}\text { Технологія } \\
\text { зберігання }\end{array}$ & Переваги & Недоліки & $\begin{array}{l}\text { Кількість } \\
\text { циклів }\end{array}$ & $\begin{array}{c}\text { Ефективність, } \\
\%\end{array}$ \\
\hline $\begin{array}{l}\text { Lead-Acid } \\
\text { Batteries } \\
\text { (свинцево- } \\
\text { кислотні } \\
\text { батареї) }\end{array}$ & $\begin{array}{c}\text { Висока продуктивність, низька } \\
\text { об’ємна щільність енергії, низькі } \\
\text { капітальні витрати, тривалий } \\
\text { термін служби }\end{array}$ & $\begin{array}{c}\text { Низький ККД, } \\
\text { несприятливий вплив } \\
\text { на навколишнє } \\
\text { середовище }\end{array}$ & $\begin{array}{c}200 \div \\
300\end{array}$ & 75 \\
\hline $\begin{array}{l}\text { Sodium-Sulfur NaS } \\
\text { batteries (натрій- } \\
\text { сірка } \mathrm{NaS} \text { ) }\end{array}$ & $\begin{array}{c}\text { Дуже висока енергетична } \\
\text { потужність, висока енергетична } \\
\text { щільність, тривалий термін } \\
\text { служби }\end{array}$ & $\begin{array}{c}\text { Витрати на } \\
\text { виробництво, } \\
\text { проблеми безпеки }\end{array}$ & $\begin{array}{c}2000 \div \\
3000\end{array}$ & 89 \\
\hline $\begin{array}{l}\text { Metal-Air } \\
\text { batteries }\end{array}$ & Дуже висока щільність енергії & $\begin{array}{l}\text { Мало доступних } \\
\text { акумуляторних } \\
\text { батарей }\end{array}$ & $\begin{array}{c}100 \div \\
200\end{array}$ & 50 \\
\hline Li-Ion batteries & $\begin{array}{c}\text { Дуже високий ККД і щільність } \\
\text { енергії }\end{array}$ & $\begin{array}{l}\text { Низька кількість } \\
\text { життєвих циклів }\end{array}$ & $\begin{array}{c}300 \div \\
500\end{array}$ & 95 \\
\hline Flow battery & $\begin{array}{c}\text { Дуже висока енергоємність і } \\
\text { потужність, тривалий термін } \\
\text { служби }\end{array}$ & $\begin{array}{c}\text { Низька щільність } \\
\text { енергії, низький } \\
\text { ККД }\end{array}$ & $\begin{array}{c}1500 \div \\
2500\end{array}$ & $75 \div 85$ \\
\hline $\begin{array}{l}\text { Super-capacitors } \\
\text { (суперконденсатор } \\
\text { и) }\end{array}$ & Високий ККД & $\begin{array}{l}\text { Низька енергетична } \\
\text { щільність, мало } \\
\text { енергетичних } \\
\text { систем }\end{array}$ & $10^{4} \div 10^{5}$ & $93 \div 98$ \\
\hline $\begin{array}{l}\text { Flywheel } \\
\text { energy storage } \\
\text { (FES) }\end{array}$ & $\begin{array}{c}\text { Висока потужність, короткий час } \\
\text { доступу, тривалий термін служби, } \\
\text { низькі зусилля технічного } \\
\text { обслуговування, високий ККд, } \\
\text { малі екологічні наслідки }\end{array}$ & $\begin{array}{c}\text { Низька щільність } \\
\text { енергї }\end{array}$ & $10^{5} \div 10^{7}$ & 90 \\
\hline
\end{tabular}


Найбільш поширеним типом батарей для PHEV i BEV в даний час $€$ літій-іонні батареї. Основна причина дорогої ціни електромобіля - це вартість батареї.

Для сучасних електромобілів існує безліч виробництв літій-іонних акумуляторів, більшість 3 яких знаходяться в стадії розроблення. Дослідники можуть вибрати електроліт, позитивний і негативний електроди, щоб оптимізувати продуктивність, безпеку та довговічність батареї [10].
Існує тенденція зменшення вартості Li-ion батарей. За існуючими пронозами, у 2030 р. вартість електромобіля буде меншою, ніж вартість автомобіля 3 ДВЗ (рис. 1).

Заряджання електромобіля зазвичай на $80 \div 90 \%$ дешевше, ніж заправка бензинових автомобілів. Електромобілі споживають від 16 до 25 кВт·год енергії на 100 км. Залежно від вартості електроенергії 100 км ходу коштуватимуть $10 \div 30$ грн.



Рис. 1. Залежність вартості автомобілів і комплектуючих за роками: 1 - вартість автомобіля 3 двигуном внутрішнього згорання; 2 - вартість батареї; 3 - вартість трансмісії; 4 - вартість електромобіля

Батарейний відсік в автомобілі Tesla S має ємність батарей виробництва компанії Рanasonic типу NCR85 кВт·год і складається з 7104 шт. (16 блоків, у яких 18650 [11] (рис. 2). знаходиться 6 груп по 74 елементи) літій-іонних

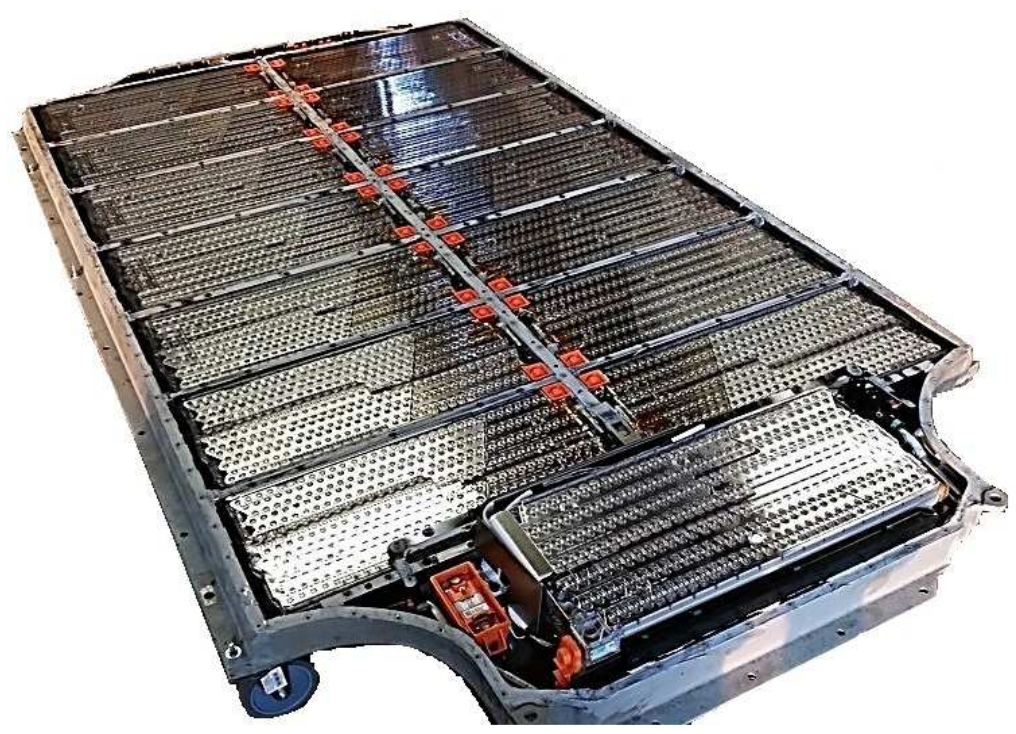

Рис. 2. Батарейний відсік з батареями типу NCR 18650 в Tesla S 
У табл. 2 наведено технічні характеристики батареї типу NCR 18650.

Таблиця 2

Технічні характеристики батареї типу NCR 18650

\begin{tabular}{|c|c|c|}
\hline \multicolumn{2}{|c|}{ Номінальна ємність, мА·год } & 3200 \\
\hline \multicolumn{2}{|c|}{ Номінальна напруга, В } & 3,6 \\
\hline \multicolumn{2}{|c|}{ Час повного заряджання, год } & 4 \\
\hline \multicolumn{2}{|l|}{ Вага, г } & 48,5 \\
\hline \multirow[t]{2}{*}{ Температура, ${ }^{\circ} \mathrm{C}$} & заряджання & $0 \div 45$ \\
\hline & розряджання & $-20 \div 60$ \\
\hline \multicolumn{2}{|c|}{ Щільність енергії, Вт/кг } & 243 \\
\hline
\end{tabular}

Літій-іонні акумулятори пошкоджуються при перевищенні певної верхньої межі напруги через виникнення небажаних вторинних електрохімічних реакцій [12]. Також відомо, що подача занадто високого струму може призвести до гальванізації літію на негативному електроді, що у свою чергу призводить до зміни міжфазної фази твердого електроліту та постійно погіршує робочі характеристики батареї [13].

Швидкість заряджання та розряджання акумулятора визначається С-нормою [14]. Ємність батареї зазвичай оцінюється в $1 \mathrm{C}$, що означає, що повністю заряджена батарея, розрахована на $1 \mathrm{~A} \cdot$ год, повинна забезпечувати 1 А протягом однієї години. Одна й та сама батарея, що не розряджається при $0,5^{\circ} \mathrm{C}$, повинна забезпечувати 500 мА протягом 2 год, а при $2{ }^{\circ} \mathrm{C}-2$ А протягом 30 хв. Втрати при швидких розрядах скорочують час розряджання, i ці втрати також впливають на час заряджання. У табл. 3 наведено значення часу при різних С-нормах.

Таблиця 3

Залежність часу від різних С-норм

\begin{tabular}{|l|l|}
\hline \multicolumn{1}{|c|}{ С-норма } & \multicolumn{1}{c|}{ Час } \\
\hline $5 \mathrm{C}$ & 12 хв \\
\hline $2 \mathrm{C}$ & 30 хв \\
\hline $1 \mathrm{C}$ & 1 год \\
\hline $0.5 \mathrm{C}$ & 2 год \\
\hline $0.2 \mathrm{C}$ & 5 год \\
\hline $0.1 \mathrm{C}$ & 10 год \\
\hline $0.05 \mathrm{C}$ & 20 год \\
\hline
\end{tabular}

Характеристики заряджання-розряджання однієї батареї типу NCR 18650 наведено на рис. 3.

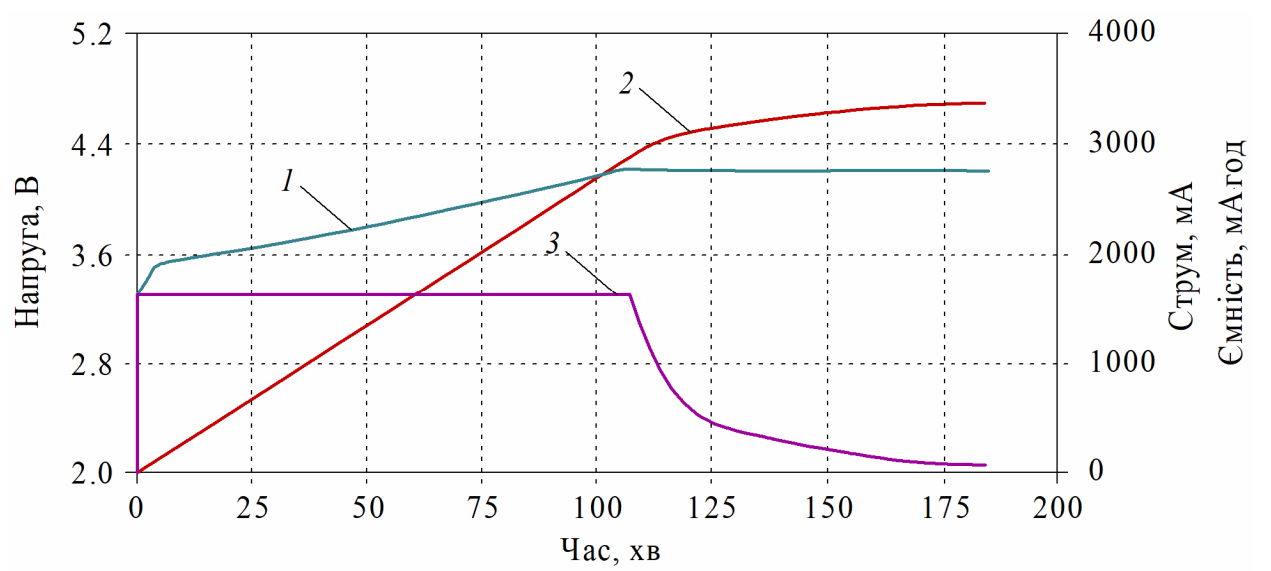

a)

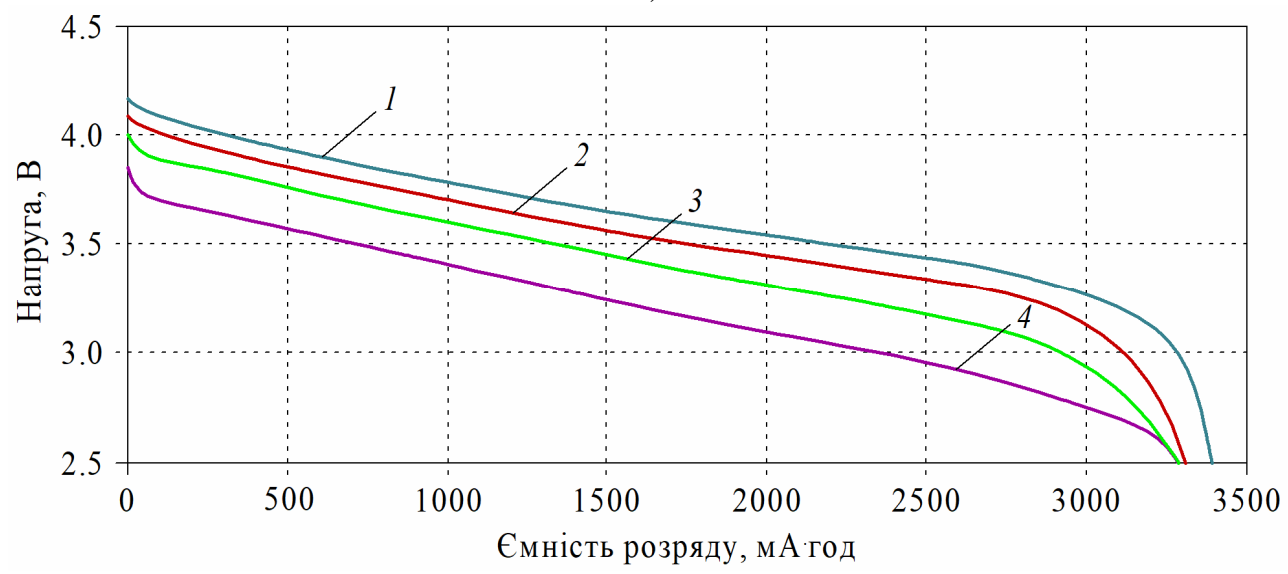

б)

Рис. 3. Перехідні процеси в батареї типу NCR 18650:

$a$ - заряд батареї ( 1 - напруга, 2 - ємність, 3 - струм); б - розряд батареї (1 - 0.2 C, 2 - 0.5 C, 3 - 1 C, 4 - 2 C) 
На рис. 4 наведено характеристики електромобіля Tesla Model S85 при заряджанні.

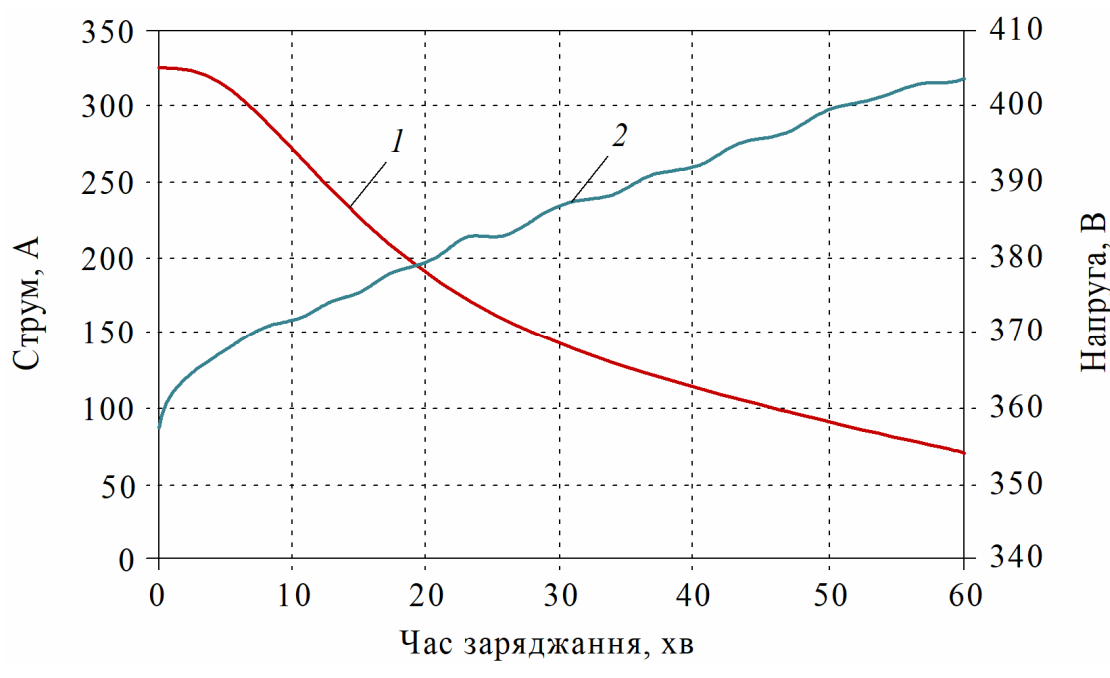

a)

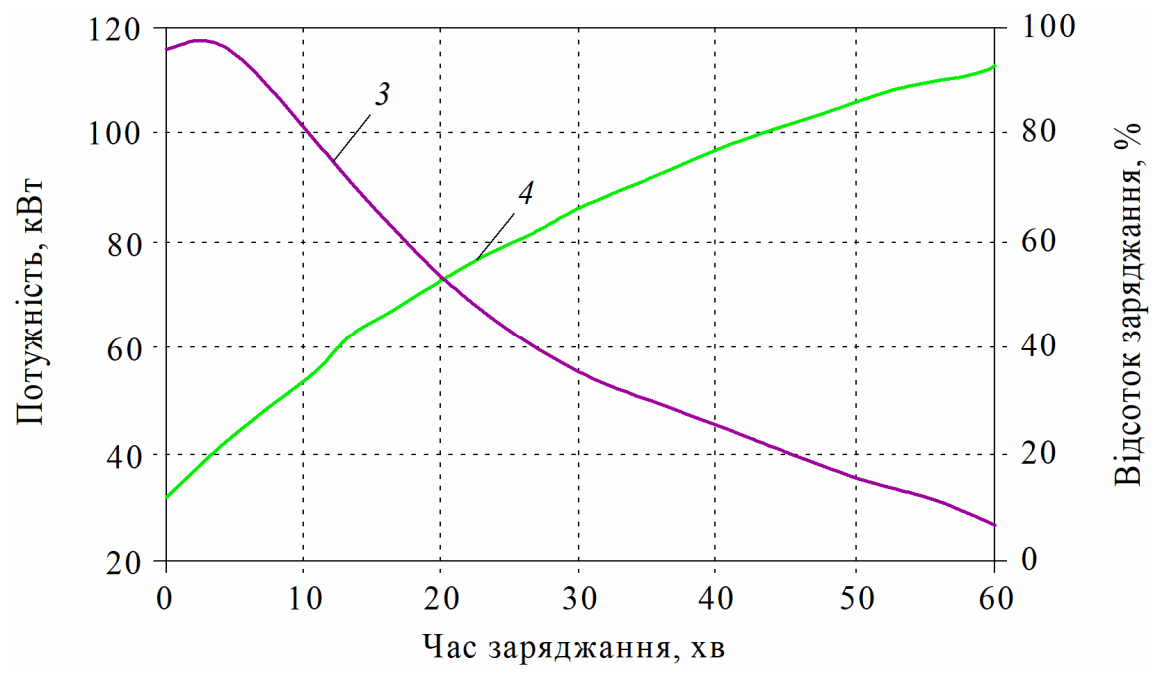

б)

Рис. 4. Характеристики електромобіля Tesla Model S85 при заряджанні: $a$ - струм (1) і напруга (2), 6 - потужність (3) і відсоток заряду (4)

У стандарті IEC 62196, чинному в Свропі, виділено такі режими заряджання [15].

Тип 1. Пряме пасивне підключення до електромережі змінного струму. Підключення не вимагає додаткових керуючих пристроїв. Це домашнє заряджання від стандартної розетки 3 простим подовжувачем, без будь-яких заходів безпеки. Заряджання здійснюється змінним струмом 16 А і напругою 230 В з піковою потужністю до 3,3 кВт.

Тип 2. Пряме підключення транспортного засобу до мережі живлення змінним струмом, тобто заряджання в домашніх умовах від звичайної розетки, але 3 використанням спеціального адаптера, що входить до комплекту з новим електромобілем. Цей адаптер забезпечує заземлення, захист від різкого перепаду напруги, температурний захист. Адаптери Mode 2 гарантують середній рівень безпеки та $\epsilon$ мінімальною нормою для заряджання авто. Заряджання здійснюється змінним струмом до 32 А і напругою 230 В з піковою потужністю до 7,4 кВт.

Тип 3. Активне підключення електромобіля до дротової зарядної станції змінного струму 3 заземленням i приладами керування, а також адаптером 3 додатковими струмопровідними жилами. 
Заряджання здійснюється трифазним змінним струмом до 63 А напругою 400 В 3 піковою потужністю до 43 кВт.

Тип 4. Підключення електромобіля до дротової станції постійного струму. Обладнання для заряджання електромобілів $є$ проміжною ланкою між джерелом живлення та зарядним портом транспортного засобу. Його роль полягає в тому, щоб подати постійний струм в автомобіль безпечно та швидко. У зарядних станціях постійного струму зарядний пристрій є частиною станції, а не автомобіля. Швидке заряджання постійним струмом допускає зарядний струм до 500 А напругою $400 \div 500 \mathrm{~B} 3$ максимальною піковою потужністю до 250 кВт.

Наприклад, автомобіль Tesla обладнаний як бортовим зарядним перетворювачем електроенергії, який дозволяє заряджати блок батареї зарядами типу 1 , 2, 3, так i зовнішнім зарядним пристроєм, який дозволяє заряджати блок батареї зарядами типу 4 [16].

Оскільки технології EV удосконалювалися, а електрифіковані перевезення стали більш поширеними, виникла потреба в стандартних портах для заряджання. Як водій транспортного засобу 3 двигуном внутрішнього згоряння може заправлятися на будь-якій заправці, така сама потреба виникла для електромобілів. Навіть сьогодні відсутність стандартизації зарядного порту $\epsilon$ основною перешкодою, яка стримує прийняття $\mathrm{EV}$, оскільки різні виробники $\mathrm{EV}$, як i раніше, використовують різні конфігурації зарядних портів. Товариство інженерів автомобільної промисловості (SAE - The Society of Automotive Engineers) існує 3 метою об'єднання та розвитку технологій шляхом створення загальноприйнятих стандартів у галузі. У 1996 р. SAE випустила свій перший стандарт з'єднувача для електропроводного заряду EV, який до сьогоднішнього дня неодноразово переглядався. Інші стандарти електромобілів для електромобілів і гібридних електромобілів (PHEV), які SAE розробило протягом багатьох років, включають J2954 (стандарт бездротової передачі енергіi), J3068 (стандарт трифазного провідного заряду) та інші різні стандарти, які стосуються стандартів зв'язку та вимірювання ККД транспортних засобів.

Оскільки технологія EV продовжує розвиватися, ідея повинна полягати в тому, що виробники будуть об'єднуватися в один порт для підключення. Чотирма основними зарядними рознімачами, що з'являються на ринку сьогодні, $€$ північноамериканський $\operatorname{CCS} 1$, європейський CCS 2, CHAdeMO (стандарт, розроблений в Японії й Китаї) i Tesla Super Charger [17].

У табл. 4 наведено характеристики зовнішніх зарядних станцій.

У табл. 5 наведено класифікацію штекерів комутаційних зарядних пристроїв.

Таблиця 4

Характеристики зовнішніх зарядних станцій

\begin{tabular}{|c|c|c|c|c|c|}
\hline Виробник і модель & $\begin{array}{l}\text { ABB Terra } \\
53\end{array}$ & $\begin{array}{c}\text { Tritium } \\
\text { Veefil-RT }\end{array}$ & $\begin{array}{l}\text { Tesla } \\
\text { Super- } \\
\text { charger }\end{array}$ & $\begin{array}{l}\text { EVTEC } \\
\text { espresso\& } \\
\text { charge }\end{array}$ & $\begin{array}{c}\text { ABB Terra } \\
\text { HP }\end{array}$ \\
\hline $\begin{array}{l}\text { Номінальна потужність, } \\
\text { кВт }\end{array}$ & 50 & 50 & 135 & 150 & 350 \\
\hline Стандарт & $\begin{array}{c}\text { CCS } \\
\text { Type 1 } \\
\text { CHAde } \\
\text { MO } 1.0\end{array}$ & $\begin{array}{c}\text { CCS Types } \\
1 \text { and } 2 \\
\text { CHAde } \\
\text { MO } 1.0\end{array}$ & $\begin{array}{l}\text { Super- } \\
\text { charger }\end{array}$ & $\begin{array}{c}\text { SAE } \\
\text { Combo } 1 \\
\text { CHAdeMO } 1.0\end{array}$ & $\begin{array}{c}\text { SAE } \\
\text { Combo 1 } \\
\text { CHAdeMO } 1.2\end{array}$ \\
\hline Напруга живлення & $\begin{array}{l}480 \\
\text { VAC }\end{array}$ & $\begin{array}{c}380 \div 480 \\
\text { VAC } \\
600 \div 900 \\
\text { VDC }\end{array}$ & $\begin{array}{l}200 \div 480 \\
\text { VAC }\end{array}$ & $\begin{array}{l}400 \mathrm{VAC} \\
\pm 10 \%\end{array}$ & $\begin{array}{l}400 \mathrm{VAC} \\
\pm 10 \%\end{array}$ \\
\hline $\begin{array}{l}\text { Вихідна напруга } \\
\text { постійного струму, В }\end{array}$ & $\begin{array}{c}200 \div 500 \\
50 \div 500\end{array}$ & $\begin{array}{c}200 \div 500 \\
50 \div 500\end{array}$ & $50 \div 410$ & $170 \div 500$ & $150 \div 920$ \\
\hline $\begin{array}{l}\text { Вихідний постійний } \\
\text { струм, А }\end{array}$ & 120 & 125 & 330 & 300 & 375 \\
\hline Енергоефективність, \% & 94 & $>92$ & 92 & 93 & 95 \\
\hline
\end{tabular}


Класифікація штекерів комутаційних зарядних пристроїв

\begin{tabular}{|c|c|c|c|c|}
\hline \multirow{3}{*}{$\begin{array}{l}\text { Системи за } \\
\text { прийнятими } \\
\text { стандартами }\end{array}$} & \multirow{2}{*}{$\begin{array}{c}\text { System A } \\
\text { CHAdeMO } \\
\text { (Japan) }\end{array}$} & \multirow{2}{*}{$\begin{array}{c}\text { System B } \\
\text { GB/T } \\
\text { (PRC) }\end{array}$} & \multicolumn{2}{|c|}{ System C } \\
\hline & & & Combo1 (US) & Combo2 (DE) \\
\hline & & & & \\
\hline $\begin{array}{l}\text { Рознімач } \\
\text { автомобіля }\end{array}$ & & & & \\
\hline Протокол зв'язку & \multicolumn{2}{|c|}{ CAN } & \multicolumn{2}{|c|}{ PLC } \\
\hline
\end{tabular}

CHAdeMO - це швидкодіючий штекер постійного струму, який може заряджати до 62,5 кВт, і в даний час працюють над технологіями, які можуть заряджати до 200 кВт. Останнім часом CHAdeMO зроблено великий крок у напрямку глобального стандарту заряджання електромобілів, запрошуючи виробників автомобілів з усього світу взяти участь у розробленні. Новий стандарт дозволить забезпечити потужність понад 900 кВт (1500 В, 600 А). Можливості обробки високої потужності дозволять використовувати цей стандарт протягом декількох років, оскільки технології заряджання акумуляторів продовжують розвиватися, забезпечуючи більш високу потужність заряду. Останній надшвидкий Supercharger V3 від Tesla може мати вихідну потужність до 250 кВт на автомобіль і в кінцевому підсумку скоротити час заряджання в середньому на $50 \%$.

Кожен виробник автомобілів у наш час обирає або стандарт CHAdeMO, або стандарт CCS, причому азіатські автовиробники використовують CHAdeMo, у той час як більшість європейських і американських виробників використовують CCS, a Tesla використовує свій власний зарядний з'єднувач, популярність якого в останній час зросла. Відсутність глобального стандарту викликало у споживачів більшу плутанину, i разом 3 високими цінами саме спосіб заряджання акумуляторів і відсутність загальноприйнятого стандарту не дозволило широко розповсюдити електромобілі. Тому подальший розвиток технологій і стандартів зарядних пристроїв призведе до поширення електромобілів у суспільстві.

\section{Висновки i рекомендації щодо подальшого використання}

Електромобілі $\epsilon$ перспективним напрямком розвитку інфраструктури та транспорту. Майже всі міжнародні автомобільні корпорації (BMW, Opel, Mercedes, Tesla, Nissan і т. п.) інвестують суттєві кошти в розвиток електромобілебудування. Одним 3 найважливіших показників електромобілей $є$ заряднорозрядні характеристики акумуляторних батарей i їхніх зарядних пристроїв. Це пов'язано 3 максимальною дальністю ходу за одне заряджання акумулятора та ККД, тобто фактичними фінансовими витратами на електроенергію. В існуючих зарядних пристроях при значних значеннях струму заряду (типу 4) виникають великі втрати електроенергії, тому актуальним є питання розвитку власних технічних рішень щодо покращення технічних характеристик зарядних станцій електромобілей.

Надалі планується провести моделювання заряднорозрядних характеристик акумуляторів для електромобілів з використанням різних силових схем зарядних станцій та алгоритмів їхньої роботи. Необхідно провести аналіз енергетичних характеристик для оцінювання втрат енергії залежно від величини струму заряду електромобіля.

\section{Список використаних джерел}

1. Нерубацький В. П., Гордієнко Д. А. Контроль i планування енерговикористання на залізничному транспорті. Матеріали VII міжнародної науковопрактичної конференції «Людина, суспільство, комунікативні технологіï». Харків-Лиман, 2019. C. 227-230.

2. Nerubatskyi V., $\quad$ Plakhtii O., $\quad$ Ananieva O., Zinchenko O. Analysis of the Smart Grid concept for DC power supply systems. International scientific journal «INDUSTRY 4.0». 2019. Vol. 4, Issue 4. P. $179-182$.

3. Franco V., Zacharopoulou T., Hammer J., Schmidt H., Mock P., Weiss M., Samaras V. Evaluation of exhaust 
emissions from three diesel-hybrid cars and simulation of after-treatment systems for ultralow real-world $\mathrm{NO}_{\mathrm{X}}$ emissions. Environ. Sci. Technol. 2016. Vol. 50, Issue 37. P. 13151-13159.

DOI: 10.1021/acs.est.6b03585.

4. Coffman M., Bernstein P., Wee S. Electric vehicles revisited: a review of factors that affect adoption. Transport Reviews. 2016. Vol. 37. P. 79-93. DOI: 10.1080/01441647.2016.1217282.

5. Weiss M., Zerfass A., Helmersb E. Fully electric and plug-in hybrid cars. An analysis of learning rates, user costs, and costs for mitigating $\mathrm{CO} 2$ and air pollutant emissions. Clean Prod. 2019. Vol. 212. P. 1478-1489. DOI: 10.1016/j.jclepro.2018.12.019.

6. Нерубацький В. П., Плахтій О. А., Гордієнко Д. А., Соловйов Д. В., Ц Цибульник В. Р. Розробка конструктиву засувки промислового приладу для кріплення на DIN-рейку. Збірник наукових праць Українського державного університету залізничного транспорту. Харків: УкрдУзТ, 2018. Вип. 180. С. 88-95.

7. Giechaskiel B., Riccobono F., Vlachos T., MendozaVillafuerte P., Suarez-Bertoa R., Fontaras G., Bonnel P., Weiss M. Vehicle emission factors of solid nanoparticles in the laboratory and on the road using Portable Emission Measurement Systems (PEMS). Frontiers in Environmental Science. 2015. Vol. 3. P. 82-83. DOI: 10.3389/fenvs.2015.00082.

8. Haq G., Weiss M. Time preference and consumer discount rates - insights for accelerating the adoption of efficient energy and transport technologies. Technol. Forecast. Soc. Change. 2018. Vol. 137. P. 76-88. DOI: 10.1016/j.techfore.2018.06.045.

9. Hardman S., Chandan A., Tal G., Turrentine T. The effectiveness of financial purchase incentives for battery electric vehicles - a review of the evidence. Renew. Sustain. Energy Rev. 2017. Vol. 80. P. 11001111. DOI: 10.1016/j.rser.2017.05.255.

10. Helmers E. Possible resource restrictions for the future large-scale production of electric cars. Competition and Conflicts on Resource Use, Natural Resource Management and Policy. 2015. Vol. 46. P. 121-131. DOI: 10.1007/978-3-319-10954-1_9

11. Levay P. Z, Drossinos Y., Thiel C. The effect of fiscal incentives on market penetration of electric vehicles: a pairwise comparison of total cost of ownership. Energy Pol. 2017. Vol. 105. P. 524-533. DOI: 10.1016/j.enpol.2017.02.054.

12. Safari M. Battery electric vehicles: looking behind to move forward. Energy Pol. 2017. Vol. 115. P. 54-65. DOI: 10.1016/j.enpol.2017.12.053.

13. Ciez R. E., Whitacre J. F. The cost of lithium is unlikely to upend the price of $\mathrm{Li}$-ion storage systems. Power Sources. 2016. Vol. 320. P. 310-313. DOI: 10.1016/j.jpowsour.2016.04.073.
14. Helmers E., Weiss M. Advances and critical aspects in the life-cycle assessment of battery electric cars. Energy Emiss. Control Technol. 2017. Vol. 5. P. 118. DOI:10.2147/EECT.S60408.

15. Nilsson M., Nykvist B. Governing the electric vehicle transition - near term interventions to support a green energy economy. Appl. Energy. 2016. Vol. 179. P. 1360-1371. DOI: 10.1016/j.apenergy.2016.03.056.

16. Weiss M., Dekker P., Moro A., Scholz H., Patel M. On the electrification of road transportation - a review of the environmental, economic, and social performance of electric two-wheelers. Transport. Res. Transport Environ. 2015. Vol. 41. P. 348-366. DOI: 10.1016/j.trd.2015.09.007.

17. Helmers V, Dietz J., Hartard S. Electric car LCA based on real-world mileage and the electric conversion scenario. Int. J. Life Cycle Assess. 2017. Vol. 22. P. 15-30. DOI: 10.1007/s11367-015-0934-3.

$\begin{array}{ll}\text { В. П. Нерубацкий, } & \text { А. А. Плахтий, } \\ \text { Д. А. Гордиенко. } & \text { Анализ Машура, }\end{array}$ характеристик аккумуляторных батарей и систем зарядки электромобилей.

Аннотация. В статье представлена классификация электромобилей и проведен обзор технических характеристик аккумуляторных батарей и их систем зарядки. На сегодняшний день наиболее перспективными являются литий-ионные аккумуляторы. Они имеют следующие преимущества: высокий коэффициент полезного действия в процессе зарядки-разрядки, высокую плотность электрической энергии (кВт.ч/кг). При этом относительным недостатком литий-ионных аккумуляторов есть небольшое количество циклов зарядки-разрядки (около 500 циклов), что соответствует примерно 250 тыс. км для электромобиля Tesla Model S, после чего аккумуляторную батарею необходимо заменить.

Представлены базовые энергетические параметры и зарядно-разрядные характеристики литий-ионных аккумуляторов, используемых в электромобилях Tesla.

Выделены и классифицированы четыре типа зарядных станций, по которым первый тип описывает процесс зарядки электромобиля непосредственно от однофазной сети. Второй тип имеет разницу от первого наличием электрической защиты. Третий тип - зарядка электромобиля трёхфазным напряжением переменного тока. Четвёртый тип - зарядка постоянным током и большой мощностью, что позволяет быстрее проводить процесс заряда.

Ключевые слова: аккумуляторная батарея, двигатель, источник питания, электромобиль, зарядно-разрядные характеристики, литий-ионный аккумулятор. 
V. P. Nerubatskyi, O. A. Plakhtii, A. V. Mashura, D. A. Hordiienko. Analysis of technical characteristics of batteries and electric car charging systems.

Abstract. Electric cars are a promising area for the development of infrastructure and transport. Almost all international automotive corporations are investing heavily in the development of electric vehicles.

The article presents the classification of electric vehicles and reviews the technical characteristics of batteries and their charging systems. To date, the most promising are lithium-ion batteries. They have the following advantages: high efficiency in the process of charge-discharge, high density of electric energy $(\mathrm{kW} \cdot \mathrm{h} / \mathrm{kg})$. At the same time, the relative disadvantage of lithium-ion batteries is the small number of chargedischarge cycles (about 500 cycles), which corresponds to about 250 thousand $\mathrm{km}$ for the Tesla Model S electric car, after which the battery must be replaced.

The basic energy parameters and charge-discharge characteristics of lithium-ion batteries used in Tesla electric vehicles are presented.

Four types of charging stations are identified and classified. According to what the first type - describes the process of charging an electric vehicle directly from a single-phase network. The second type has a difference from the first by the presence of electrical protection. The third type is the charge of an electric vehicle with a threephase AC voltage. The fourth type is a charge with direct current and high power, which makes it possible to carry out the charge process faster.

The types of internationally standardized plugs for charging electric vehicles are considered: CHAdeMO - a standard developed in Japan and China, CSS1 - North American, CSS2 - European and TeslaSupercharger standard.

One of the most important indicators of electric vehicles is the charge-discharge characteristics of batteries and their chargers. This is due to the maximum range for one battery charge and efficiency, that is, the actual financial cost of electricity. In existing chargers with significant values of the charge current (type 4 charging), large losses of electricity occur, therefore, the issue of developing our own technical solutions to improve the technical characteristics of charging stations of electric vehicles is relevant.

Key words: rechargeable battery, engine, power supply, electric vehicle, charge-discharge characteristics, lithiumion battery.
Нерубацький Володимир Павлович, к.т.н., доцент кафедри електроенергетики, електротехніки та електромеханіки. Украйнський державний університет залізничного транспорту. E-mail: NVP9@i.ua_ORCID: https://orcid.org/0000-0002-4309$\underline{601 X}$

Плахтій Олександр Андрійович, к.т.н., доцент кафедри електроенергетики, електротехніки та електромеханіки. Украйнський державний університет залізничного транспорту. ORCID: https://orcid.org/0000-0002-1535-8991 E-mail: a.plakhtiy1989@gmail.com

Машура Артем В'ячеславович, аспірант кафедри промислової та біомедичної електроніки. Начіональний технічний університет «Харківський політехнічний iнститут». E-mail: artemmashura94@gmail.com ORCID: https://orcid.org/0000-0002-6016-7801

Гордіснко Денис Анатолійович, аспірант кафедри електроенергетики, електротехніки та електромеханіки. Український державний університет залізничного транспорту. E-mail: D.Hordiienko@i.ua_ORCID: https://orcid.org/0000-00020347-5656

Nerubatskyi Volodymyr Pavlovych, PhD, associate professor department of electric power engineering, electrical engineering and electromechanics. Ukrainian State University of Railway Transport. ORCID: https://orcid.org/0000-0002-4309-601X E-mail: NVP9@i.ua

Plakhtii Olexandr Andrievych, PhD, associate professor department of electric power engineering, electrical engineering and electromechanics. Ukrainian State University of Railway Transport. ORCID: https://orcid.org/0000-0002-1535-8991 E-mail: a.plakhtiy1989@gmail.com

Mashura Artem Vyacheslavovych, postgraduate of the pulpit of Industrial and Biomedical Electronics. National Technical University «KhPI». E-mail: artemmashura94@gmail.com ORCID: https://orcid.org/0000-0002-6016-7801

Hordiienko Denys Anatolievych, postgraduate, epartment of electric power engineering, electrical engineering and electromechanics, Ukrainian State University of Railway Transport. E-mail: D.Hordiienko@i.ua ORCID: https://orcid.org/0000-0002-0347-5656 